\title{
A ética do trote
}

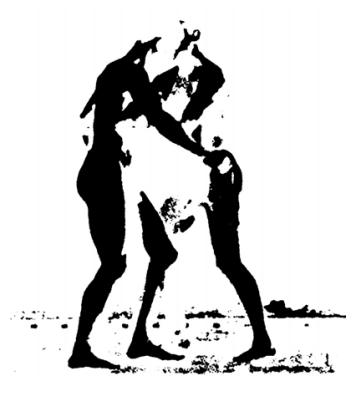

Pedro Geraldo Aparecido Novelli ${ }^{1}$

O trote é uma maneira de recepcionar os calouros que ingressam na universidade. Os alunos veteranos são geralmente seus articuladores diretos do trote. A instituição universitária não reconhece oficialmente o trote como a forma mais adequada de recepção embora articule o trote indiretamente, pois acaba aceitando sua prática ou por incentivo de alguns de seus setores ou por não tratar da questão com a devida consideração. Ser acolhido e ser recepcionado representa um deferimento em relação a quem chega e pode também ser gratificante para o mesmo. Quem recepciona dá mostras de respeitabilidade porque reconhece o outro em sua novidade. Contudo, pode-se ser indelicado, agressivo, violento em nome da recepção $e$, mais ainda, se a recepção estiver envolvida por clima de jocosidade no qual podem ocorrer fatos reais com pretensão de ficção. A recepção pressupõe uma certa gratuidade, pois é iniciativa de quem recepciona. Por isso, o recepcionado tem o direito de aceitar ou não a forma da recepção. Quem recepciona deve pensar mais em si ou no outro ? A minha alegria é a alegria do outro? A alegria é a mesma para o outro e para mim? Quem pretende amar deve indagar-se sobre a própria forma de amar. Um amor ininteligente pode ser pior do que o ódio (Hegel).

${ }^{1}$ Filósofo, professor do Departamento de Educação do Instituto de Biociências de Botucatu, Unesp. 
Como não se pode contar com o bom senso das pessoas mesmo que muitas digam possuí-lo até demais, faz-se necessário o estabelecimento de balizas norteadoras do comportamento. Em nome do trote pode-se criar o "vale tudo". Aqui as leis são outras e as conseqüências e a responsabilidade por elas não cabem a ninguém. Não se tem aqui um Estado dentro do Estado ou ainda a carnavalização do próprio Estado? Há um momento de suspensão de todo estado de direito e de dever? Que privilégio é esse? A quem se deve prestar contas ? Nesse sentido o trote precisa ser incorporado oficialmente pela comunidade universitária e discutido amplamente para que as diversas posições sejam claramente postas. Recepcionar é necessário e possível, mas talvez não o seja nos moldes do trote indiscriminado. A ciência, a religião que possuem um longo histórico marcado pela busca da seriedade destruíram (destróem?) vidas. A sociedade deve estar atenta ao que ela mesma produz para que não venha a gestar a própria morte pelo menos em termos absolutos. O que é bom pode tornar-se mau se empregado indevidamente. Não se pode fazer algo inconseqüente, principalmente quando a vida está envolvida. Como a vida deve ser tratada constitui-se uma questão ética. Trata-se de definir comportamentos que sejam aceitáveis. A ética implica um sujeito ético que deve ser livre e consciente, isto é, sabedor e responsável em relação ao que faz, pois faz para e com alguém mais. A liberdade e a responsabilidade somente existem devido ao outro. A desconsideração do outro indica uma determinada ética que garante a satisfação de determinados interesses.

Professores e alunos ensinam e aprendem mutuamente mesmo quando acreditam não o estar fazendo. Todo professor ensina moral mesmo que não o queira. Todo aluno aprende moral mesmo que não o queira. Mas, qual moral é ensinada e aprendida ? O trote é um momento de ensino $e$ aprendizagem: o que se pretende ensinar e aprender com ele? A resposta a essas perguntas passa necessariamente pela ampla discussão do próprio trote dentro de um espaço formal de ensino como a universidade.

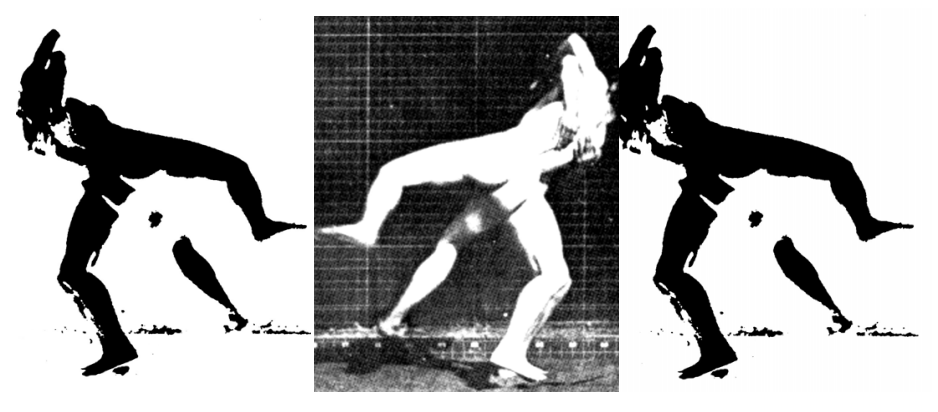

132 Interface - Comunic, Saúde, Educ 5 